\title{
Feeding trials with lysine- and threonine-fortified rice
}

\author{
By SHEILA M. PEREIRA, SHEILA JONES, \\ G. JESUDIAN AND ALMAS BEGUM \\ Nutrition Research Unit, Christian Medical College and Hospital, Vellore, Tamil \\ Nadu, India
}

(Received ${ }_{4}$ October $1972-$ Accepted 30 Fanilary 1973)

\begin{abstract}
I. The effect of fortification of rice with lysine and threonine (at levels of $2 \mathrm{~g}$ and $\mathrm{I} \mathrm{g} / \mathrm{kg}$ respectively) on the growth of preschool children was assessed in feeding trials at a residential orphanage and a village day-care centre.

2. In the first trial, the children at the orphanage were offered a diet based on rice, to provide the recommended allowances of protein and energy. For the children in the experimental group, the rice was fortified with lysine and threonine for the 6 months of the trial.

3. Statistically significant differences in final height and weight were not observed between the children in the control and in the experimental groups.

4. The children in the control group grew at optimal rates.

5. In the second trial, the diet provided approximately $80 \%$ of the daily energy and protein intakes from rice and was offered $a d l i b$. at four meals a day in the orphanage and at three meals a day in the day-care centre.

6. In the orphanage, most children ate enough of this high-bulk diet to ensure an adequate energy intake. The children given the fortified rice and those who served as controls grcw at very satisfactory rates.

7. At the village centre most of the children were unable to eat enough food to achieve an adequate intake of energy. The children given the fortified rice did not grow taller than those given unfortified rice.

8. Fortification of rice with lysine and threonine did not improve rates of growth of preschool children.
\end{abstract}

The fortification of cereals with amino acids with a view to improving the biological value of their proteins and increasing the available protein has been promulgated as one solution to the search for adequate foods for the increasing population of the world (Howe, Jansen \& Gilfillian, 1965; Altschul, 1967; Howe, Jansen \& Anson, 1967).

Fortification of cereals with appropriate amino acids is of particular relevance in countries where the majority of the population obtains almost all its daily energy and protein from the cereals consumed (Jansen \& Howe, I964).

The fortification of wheat with its most limiting amino acid, lysine, has been shown to improve rates of growth in infants (Graham, Placko, Acevedo, Morales \& Cordano, 1969; Graham, Morales, Cordano \& Placko, 1971), preschool children (Pereira, Begum, Jesudian \& Sundararaj, 1969) and schoolchildren (King, Sebrell, Severinghaus \& Storvick, I963).

Wheat flour is easily fortified with a mixture of amino acids; the supplementation of rice, which is eaten in India and the countries of South-East Asia as boiled grains, presents a more difficult problem. However, rice is the main cereal for a large part of the world's population, and its fortification with the limiting amino acids, lysine and threonine, if effective, would improve the diets of several million people.

As a step in this direction, the following studies were undertaken, to observe the 
effect of amino acid fortification of rice on the growth of preschool children, first, when they were given recommended allowances of energy and protein, and secondly, when they were given $a d l i b$.

\section{MATERIALS AND METHODS}

\section{Subjects}

Children of preschool age, i.e. 2-5 years, resident in an orphanage, took part in the first trial. They were all in apparent good health, and were allocated to an experimental and a control group, on the basis of their height, sex, age, nutritional assessment and rate of growth during the preceding 3 months.

The second trial was conducted at the residential orphanage and at a village daycare centre for preschool children. All the subjects at both centres were examined and found to be in apparently good health. They were paired and allotted to the experimental and control groups, as in the first trial.

The haemoglobin, packed cell volumes, total serum proteins and fractions were estimated at the beginning and end of each trial, which lasted for 6 months.

Weights were recorded every 2 weeks, as an average of the weights obtained on 3 consecutive days, and heights every month (an average of three readings).

Records of illness among the children were kept.

\section{Diet}

In the first study the orphanage diet was based on rice and provided $2 \mathrm{~g}$ vegetable protein and $4 \mathrm{I} 8.4 \mathrm{~kJ}$ ( $100 \mathrm{kcal}$ ) $/ \mathrm{kg}$ body-weight daily, thus supplying the recommended allowances of protein (WHO, I965) and energy (FAO, I957). Foods of animal origin were entirely excluded. Of the daily intake, $46 \%$ of the energy and $45 \%$ of the protein were provided by rice. Each child's portion was weighed out at each meal and plate waste was recorded.

In the second trial the diet was offered $a d l i b$. and was designed to provide $2 \mathrm{~g}$ vegetable protein $/ 4 \mathrm{I} 8.4 \mathrm{~kJ}$ eaten. Rice supplied $82 \%$ of the energy and $78 \%$ of the protein. The children in the orphanage were offered four meals a day and the children at the day-care centre three; generous portions were weighed out for each child at each meal and plate waste was recorded. Some of the children at the day centre ate some food in their own homes. These foods were fairly stereotyped and the quantity eaten by each child was assessed by questionnaire.

In both studies, the rice eaten by the children in the experimental and control groups came from the same batch. For the experimental group, rice fortification granules were added to the cereal in the proportion $\mathrm{I}: 99$ to provide $2 \mathrm{~g}$ lysine and $\mathrm{I} \mathrm{g}$ threonine $/ \mathrm{kg}$.

For the first 3 months of the trials the rice cooked for the experimental group was identified by mixing in a few grains impregnated with edible food colouring. After the

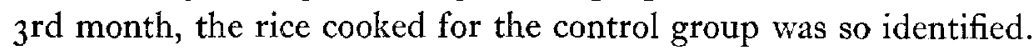


Table I. Composition of diet and daily intake of nutrients by the children in the first trial

Rice $(\mathrm{g})$
Wheat $(\mathrm{g})$
Pulses (Phaseolus
mungo) (g)
Groundnuts (g)
Vegetables (g)
Banana (g)
Vegetable oil (g)
Spices (g)
Jaggery (crude sugar) (g)

\begin{tabular}{|c|c|}
\hline 160 & Energy (kJ) \\
\hline 20 & Protein (g) \\
\hline I 5 & Fat (g) \\
\hline $\begin{array}{l}15 \\
60\end{array}$ & $\begin{array}{l}\text { Iron (mg) } \\
\text { Retinol ( } \mu \mathrm{g})\end{array}$ \\
\hline 50 & Riboflavin (mg) \\
\hline 27 & Ascorbic acid (mg) \\
\hline 14 & \\
\hline & \\
\hline
\end{tabular}

4950 ( I $83 \mathrm{kcal})$
$22 \cdot 3$
32
144
$14 \cdot 2$
$254 \cdot 4$
$0 \cdot 4$
$7 \cdot 3$

\section{Biochemical methods}

Haemoglobin was measured by the oxyhaemoglobin method using a spectrophotometer calibrated and checked at intervals with a haemoglobin standard.

Total serum proteins were determined by the biuret method and the serum protein fractions were separated by paper electrophoresis using veronal buffer $\mathrm{pH} 8 \cdot 6$, and stained with bromophenol blue. The dye was eluted with $0.01 \mathrm{M}$-sodium hydroxide (Reinhold, I953).

During the latter half of the first trial, $3 \mathrm{~d}$ nitrogen balances were measured on twelve paired children from each group. Each day's collection of urine and faeces was analysed separately. The micro-Kjeldahl method was used for the determination of urinary and faecal $\mathrm{N}$, and creatinine was estimated by Jaffe's reaction.

For 12 consecutive weeks of the first study, an average portion of the cooked foods from the experimental and control groups was homogenized and hydrolysed. All the hydrolysates of the control food were pooled and analysed for amino acid content. The hydrolysates of the portions of food from the experimental group were similarly treated.

\section{RESULTS}

First trial. Children given recommended allowances of energy and protein

The composition of the diet eaten by the children in the first study and the average daily consumption of foodstuffs and nutrients are shown in Table $\mathrm{I}$. The amino acids in the cooked foods comprising an average day's intake are given in Table 2 . Table 3 shows the threonine and lysine contents of the experimental and control diets, as calculated from standard food tables (Indian Council of Medical Research, I966) and as estimated in the cooked foods.

Twelve boys and eight girls in the experimental group and nine boys and eight girls in the control group completed the 6 months of the trial. The average heights and weights of the children in the two groups are given in Table 4 . There was no statistically significant difference between the increases in heights and weights of the children in the experimental and in the control groups $(P>0.05)$.

Statistically significant differences were not found in the values for haemoglobin, packed cell volumes, total serum proteins and serum albumin between the children in the two groups $(P>0.05)$ (Table 5). 
Table 2. Mean daily intake of amino acids from cooked foods by the children in the experimental and control groups in the first trial

\begin{tabular}{|c|c|c|c|c|}
\hline \multirow[b]{2}{*}{ Amino acid } & \multicolumn{2}{|c|}{ Experimental } & \multicolumn{2}{|c|}{ Control } \\
\hline & $\mathrm{mg}$ & $\begin{array}{c}\mathrm{mg} / \mathrm{kg} \\
\text { body-wt }\end{array}$ & $\mathrm{mg}$ & $\begin{array}{c}\mathrm{mg} / \mathrm{kg} \\
\text { body-wt }\end{array}$ \\
\hline Threonine & 556 & 46 & $5^{15}$ & 42 \\
\hline Valine & $95 \mathrm{I}$ & 78 & 913 & 75 \\
\hline Methionine & I 84 & I5 & 215 & 17 \\
\hline Isoleucine & 620 & $5 I$ & 660 & 54 \\
\hline Leucine & I 157 & 95 & 1229 & 100 \\
\hline Phenylalanine & 711 & 58 & 759 & 62 \\
\hline Lysine & 875 & 72 & 639 & 52 \\
\hline Histidine & 560 & 46 & 560 & 46 \\
\hline Cystine* & 310 & 25 & 310 & 25 \\
\hline Arginine & I I 53 & 94 & I34I & 110 \\
\hline Tyrosine & 673 & 55 & $53^{\mathrm{I}}$ & 43 \\
\hline Tryptophan* & 310 & 25 & 310 & 25 \\
\hline
\end{tabular}

* Calculated from Indian Council of Medical Research (1966).

Table 3. Mean daily intake of threonine and lysine by the children in the experimental and control groups in the first trial
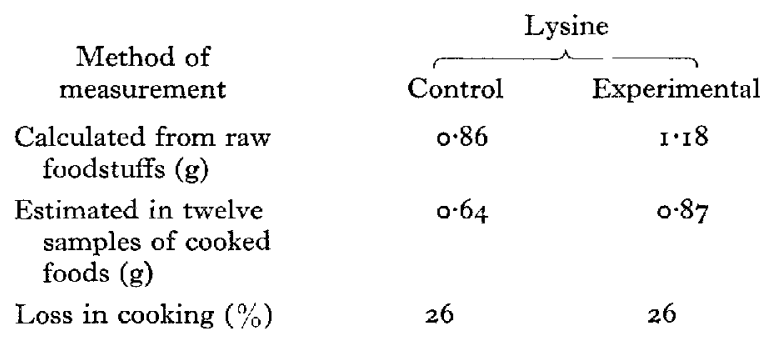

$\begin{array}{cc}\begin{array}{c}\text { Control } \\ 0.67\end{array} & 0.83 \\ 0.52 & 0.56 \\ 22 & 33\end{array}$

Table 4. Average initial and final heights and weights of the children in the control and experimental groups in the first trial

(Mean values and standard deviations)

\begin{tabular}{|c|c|c|c|c|c|c|}
\hline \multirow[b]{2}{*}{ Group } & \multicolumn{3}{|c|}{ Height (mm) } & \multicolumn{3}{|c|}{ Wt (kg) } \\
\hline & Initial & Final & Increase & Initial & Final & Increase \\
\hline $\begin{array}{l}\text { Experimental } \\
\quad \text { (12 boys, } 8 \text { girls) }\end{array}$ & $9 \circ 8 \cdot 3 \pm 54 \cdot 4$ & $942 \cdot 1 \pm 6 r \cdot 7$ & $33 \cdot 8 \pm 13 \cdot 0$ & $12 \cdot 22 \pm 1 \cdot 37$ & $12 \cdot 87 \pm 1 \cdot 59$ & $0.65 \pm 0.56$ \\
\hline $\begin{array}{l}\text { Control } \\
\quad(9 \text { boys, } 8 \text { girls })\end{array}$ & $916 \cdot 7 \pm 45 \cdot 7$ & $952 \cdot 8 \pm 4 \mathrm{I} \cdot 7$ & $36 \cdot 1 \pm$ I I 2 & $\mathrm{I} 2 \cdot 32 \pm 0.84$ & $\mathrm{r} 3 \cdot 44 \pm \mathrm{I} \cdot 02$ & $\mathrm{I} \cdot \mathrm{I} 2 \pm 0.37$ \\
\hline
\end{tabular}

The differences in apparent retention of $\mathrm{N}$ between the groups of children were not statistically significant $(P>0.05)$ (Table 6).

Second trial. Children fed ad lib.

At the orphanage, eighteen children in the experimental group (nine boys and nine girls) and seventeen children in the control group (eight boys and nine girls) completed 
Table 5. Initial and final values for total serum proteins, albumin, haemoglobin and packed cell volume $(P C V)$ of the children in the experimental and control groups in the first trial

(Mean values and standard deviations)

$\begin{array}{lcccc}\text { Group } & \begin{array}{c}\text { Total } \\ \text { protein } \\ (\mathrm{g} / 1)\end{array} & \begin{array}{c}\text { Albumin } \\ (\mathrm{g} / 1)\end{array} & \begin{array}{c}\text { Haemoglobin } \\ (\mathrm{g} / 1)\end{array} & \begin{array}{c}\text { PCV } \\ (\%)\end{array} \\ \begin{array}{l}\text { Experimental (I I boys, 8 girls) } \\ \text { Initial }\end{array} & & & & \\ \quad \text { Final } & 6 \mathrm{r} \cdot 5 \pm 4 \cdot 2 & 39 \cdot 1 \pm 3 \cdot 9 & 100 \pm \mathrm{I} 3 & 34 \cdot 4 \pm 4 \cdot \mathrm{I} \\ \text { Control (8 boys, 8 girls) } & 64 \cdot 3 \pm 4 \cdot \mathrm{I} & 40 \cdot 2 \pm 3 \cdot 9 & 113 \pm 17 & 33 \cdot 5 \pm 2 \cdot 3 \\ \quad \text { Initial } & & & & \\ \quad \text { Final } & 64 \cdot 1 \pm 5 \cdot 0 & 39 \cdot 0 \pm 3 \cdot 8 & \text { I0I } \pm \mathrm{Ir} & 33 \cdot 8 \pm 2 \cdot 7 \\ & 64 \cdot 6 \pm 4 \cdot 2 & 39 \cdot 8 \pm 5 \cdot 7 & 102 \pm 19 & 32 \cdot 6 \pm 2 \cdot 9\end{array}$

the trial. At the village centre, thirty-one children in the experimental group (fifteen boys and sixteen girls) and thirty-two children in the control group (fourteen boys and eighteen girls) attended regularly during the 6 months of the study.

The composition of the diet and the protein content of a $4 \mathrm{I} 84 \mathrm{~kJ}$ (1000 kcal) portion are given in Table 7 .

The average intake of energy was calculated for 19 weeks for all the children in the experimental and control groups at the orphanage. At the village centre, energy intakes were calculated for twenty-three children of the thirty-one in the experimental group and for twenty-five of the thirty-two children in the control group, for 18 of the 24 weeks of the trial (Table 8 ).

At the orphanage, six children in the control group and two in the experimental group were unable to eat enough food to provide a daily energy intake of $334.7 \mathrm{~kJ}$ $(80 \mathrm{kcal}) / \mathrm{kg}$ body-weight; however, only two children, in the control group, had intakes of less than $3^{1} 3.8 \mathrm{~kJ}(75 \mathrm{kcal}) / \mathrm{kg}$. At the village centre the average intake of energy was lower than that of the children at the orphanage; sixteen of the twentythree in the experimental group and twenty of the twenty-five in the control group had intakes of less than $334.7 \mathrm{~kJ}(80 \mathrm{kcal}) / \mathrm{kg}$. In the experimental group, nine children ate just the food provided at the centre. The average intake of the other fourteen was

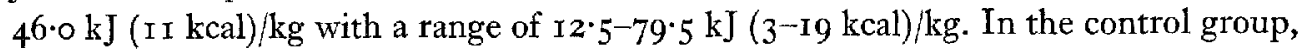
the average intake of eighteen children was $50.0 \mathrm{~kJ}(\mathrm{I} 2 \mathrm{kcal}) / \mathrm{kg}$ with a range of $12.5^{-}$ $209 \cdot 2 \mathrm{~kJ}(3-50 \mathrm{kcal}) / \mathrm{kg}$; seven children took no food other than that provided at the centre. When the food eaten in their homes was added to that eaten at the village centre, there were still nine children of the twenty-three in the experimental group and fourteen of the twenty-five in the control group whose energy intakes were less than $334.7 \mathrm{~kJ} / \mathrm{kg}$ body-weight.

The heights and weights of the children at the beginning and end of the second trial are given in Table 9. In the orphanage, the children given the rice fortified with lysine and threonine grew taller than the children in the control group, but the differences were not statistically significant $(P>0.05)$. The weights of the children in the orphanage and the heights and weights of the children at the day-care centre given the fortified rice were not significantly different from those of the children in the control groups $(P>0.05)$. 


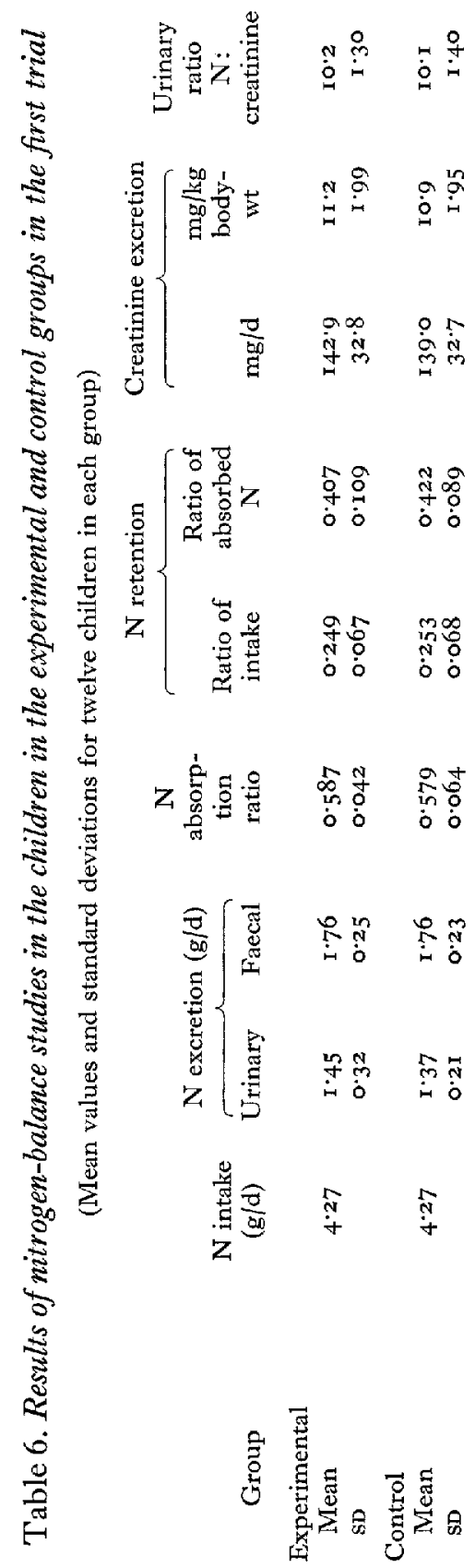


Table 7. Composition and protein content of a $4184 \mathrm{kf}(1000 \mathrm{kcal})$ portion of the high-cereal diet given to the children in the second trial

$\begin{array}{lr} & \mathrm{g} \\ \text { Parboiled rice } & 236 \cdot 4 \\ \text { Black gram dhal } & 7 \cdot 3 \\ \text { Red gram dhal } & 6 \cdot 4 \\ \text { Groundnut oil } & 9 \cdot \mathrm{I} \\ \text { Condiments } & 16 \cdot \mathbf{r} \\ \text { Onions } & 2 \mathrm{I} \cdot 8 \\ \text { Protein content } & 19 \cdot 5\end{array}$

Table 8. Average daily intake of energy ( $k \mathfrak{F} / \mathrm{kg}$ body-weight) of the children in the experimental and control groups in the second trial

\begin{tabular}{|c|c|c|}
\hline Group & $\begin{array}{c}\text { At the } \\
\text { orphanage* }\end{array}$ & $\begin{array}{c}\text { At the } \\
\text { village centret }\end{array}$ \\
\hline Experimental ( 9 boys, 9 girls) & $\begin{array}{l}368 \cdot 2 \pm 29 \cdot 3 \\
(88 \pm 7 \mathrm{kcal})\end{array}$ & $\begin{array}{c}314 \cdot 0 \pm 54.4 \\
(75 \pm 13 \mathrm{kcal})\end{array}$ \\
\hline Control ( 8 boys, 9 girls) & $\begin{array}{c}359 \cdot 8 \pm 46 \cdot 0 \\
(86 \pm \text { I I kcal })\end{array}$ & $\begin{array}{c}305^{\circ} 4 \pm 41 \cdot 8 \\
(73 \pm \text { ro kcal })\end{array}$ \\
\hline
\end{tabular}

Table 9. Average heights and weights of the children in the experimental and control groups in the second trial

(Mean values and standard deviations)

\begin{tabular}{|c|c|c|c|c|c|c|}
\hline \multirow[b]{2}{*}{ Group } & \multicolumn{3}{|c|}{ Height (mm) } & \multicolumn{3}{|c|}{ Weight (kg) } \\
\hline & Initial & Final & Increase & Initial & Final & Increase \\
\hline $\begin{array}{l}\text { Experimental } \\
\text { (9 boys, } 9 \text { girls) }\end{array}$ & $901 \cdot 7 \pm 50 \cdot 9$ & $944^{\circ} \circ \pm 56 \cdot 6$ & $\begin{array}{r}\text { In the o } \\
42 \cdot 2 \pm 8 \cdot 0\end{array}$ & $\begin{array}{l}\text { rphanage } \\
\text { I } 63 \pm 1 \cdot 49\end{array}$ & $12 \cdot 44 \pm 1 \cdot 65$ & $0.81 \pm 0.32$ \\
\hline $\begin{array}{l}\text { Control } \\
\text { ( } 8 \text { boys, } 9 \text { girls) }\end{array}$ & $911 \cdot 2 \pm 55 \cdot 0$ & $949 \cdot 7 \pm 56 \cdot 3$ & $\begin{array}{l}3^{8.5} \pm 10 \cdot 0 \\
\text { At the vil }\end{array}$ & $\begin{array}{l}12 \cdot 16 \pm 1 \cdot 76 \\
\text { lage centre }\end{array}$ & $12 \cdot 79 \pm 1 \cdot 70$ & $0.62 \pm 0.4^{8}$ \\
\hline $\begin{array}{l}\text { Experimental } \\
\text { ( } 5 \text { boys, I } 6 \text { girls) }\end{array}$ & $900 \cdot 0 \pm 74 \cdot 9$ & $93 x \cdot 6 \pm 75^{\cdot} 9$ & $3 I \cdot 6 \pm 8 \cdot 9$ & II'74 $22 \cdot 21$ & $12 \cdot 56 \pm 2 \cdot 12$ & $0.81 \pm 0.64$ \\
\hline $\begin{array}{l}\text { Control } \\
\text { (I4 boys, I } 8 \text { girls) }\end{array}$ & $900 \cdot 6 \pm 66 \cdot 3$ & $93 I \cdot I \pm 66 \cdot 5$ & $30 \cdot 5 \pm 6 \cdot 8$ & I $1 \cdot 69 \pm \mathrm{I} \cdot 88$ & $12 \cdot 62 \pm I \cdot 55$ & $0.93 \pm 0.60$ \\
\hline
\end{tabular}

The values obtained for haemoglobin, packed cell volumes and serum protein and albumin at the beginning and end of the second trial are presented in Table 10. Statistically significant differences in these biochemical measurements were not observed between the children in the experimental and in the control groups either in the orphanage or at the village centre $(P>0.05)$.

Episodes of minor illness occurred in both groups of children during the trials. Upper respiratory infections, diarrhoea and skin infections were the most frequent and a few children had measles. The pattern and severity of the illnesses were not significantly different between the experimental and control groups of children. 
Table 10. Haemoglobin, packed cell volumes (PCV), total serum proteins and serum albumin of the children in the experimental and control groups at the beginning and end of the second trial

(Mean values and standard deviations)

\begin{tabular}{|c|c|c|c|}
\hline Group & $\begin{array}{l}\text { Total } \\
\text { protein } \\
(g / 1)\end{array}$ & $\begin{array}{l}\text { Albumin } \\
(\mathrm{g} / 1)\end{array}$ & $\begin{array}{l}\text { Haemoglobin } \\
(\mathrm{g} / 1)\end{array}$ \\
\hline
\end{tabular}

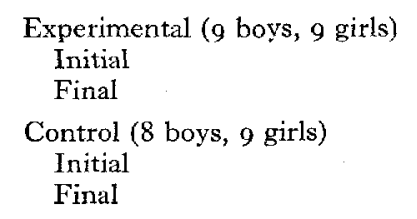

Experimental ( $\mathrm{I}_{4}$ boys, 16 girls) Initial

Final

Control (I 4 boys, I 8 girls)

Initial

Final
At the orphanage

$\begin{array}{rrrr}63 \cdot 3 \pm 3 \cdot 9 & 39 \cdot 2 \pm 3 \cdot 9 & 106 \pm 19 & 33 \cdot 4 \pm 3 \cdot 2 \\ 68 \cdot 8 \pm 2 \cdot 0 & 42 \cdot 1 \pm 3 \cdot 2 & 90 \pm 13 & 31 \cdot 4 \pm 2 \cdot 5 \\ & & & \\ 63 \cdot 6 \pm 3 \cdot 0 & 39 \cdot 5 \pm 4 \cdot 6 & 102 \pm 17 & 32 \cdot 6 \pm 3 \cdot 1 \\ 69 \cdot 1 \pm 4 \cdot 1 & 42 \cdot 2 \pm 3 \cdot 0 & 90 \pm 15 & 30 \cdot 4 \pm 3 \cdot 3\end{array}$

At the village centre

\begin{tabular}{|c|c|c|c|}
\hline $6 I 7 \pm 4.5$ & $35.7 \pm 4.0$ & IOI \pm 5 & $36 * I \pm 2 \cdot I$ \\
\hline $68 \cdot 3 \pm 4 \cdot 8$ & $42 \cdot 0 \pm 3 \cdot 4$ & $105 \pm 13$ & $33 \cdot 9 \pm 3 \cdot 4$ \\
\hline $6 r \cdot 6 \pm 5 \cdot 0$ & $37^{\circ} \pm 4^{\circ} 0$ & $104 \pm 8$ & $37.1 \pm 2.5$ \\
\hline
\end{tabular}

\section{DISCUSSION}

The diet eaten by the children who took part in the first study differed from that eaten by most preschool children in this geographical area (Sundararaj, Begum, Jesudian \& Pereira, 1969) in that it included a larger proportion of pulses and a portion of groundnuts, resulting in a slightly higher daily intake of protein and an appreciable increase in the fat content. These modifications were introduced to lessen the bulk of a high-cereal diet and to ensure an adequate daily intake of energy (FAO, 1957).

On the control diet, the children achieved a growth rate of $6 \mathrm{~mm} / \mathrm{month}$, which compares favourably with that of North American children of the same age (Nelson, I964). It is of interest that a wholly vegetarian diet, from which animal foods and milk were excluded, was able to sustain such satisfactory rates of growth.

The methionine content of the diet was low, compared with recommended allowances (Holt, György, Pratt, Snyderman \& Wallace, I960; Nakagawa, 'Takahashi \& Suzuki, I96I). From the rates of growth of the children given the diet, it must be inferred that the level of methionine was not a limiting factor. This observation is in agreement with a previous report (Begum, Radhakrishnan \& Pereira, 1970) from this laboratory on the effect of the control diet on the growth of thirteen children and with the experience of Scrimshaw, Bressani, Béhar \& Viteri(1958) and Bressani, Scrimshaw, Béhar \& Viteri ( $\left.195^{8}\right)$, who found that the addition of methionine to a maize-masa diet, to bring the level to the recommended intake, resulted in a lowered $\mathrm{N}$ retention in children.

The energy requirements of preschool children have been assessed at 502I-6276 kJ/d (1200-I500 kcal/d) (FAO, 1957; (USA) National Research Council: Food and 
Nutrition Board, I968; Indian Council of Medical Research, 1968). When expressed as $\mathrm{kJ} / \mathrm{kg}$ body-weight, using the weights of well-nourished children (Nelson, I964), a requirement of $334^{\cdot} 7^{-} 4^{0} 1^{\circ} 7 \mathrm{~kJ} / \mathrm{kg}$ is obtained. Recommended allowances are usually generous to cater for individual variations in requirement. Wait, Blair \& Roberts (1969) have recorded that active well-nourished preschool children on self-selected diets had intakes of $334^{\circ} 7 \mathrm{~kJ} / \mathrm{kg}$. In the ad lib. feeding trial, $334^{\circ} 7 \mathrm{~kJ} / \mathrm{kg}$ has been taken as a criterion of energetic adequacy.

The children in the orphanage were maintained in a more sanitary environment than those in the village. An analysis of the incidence of illness in both situations revealed that the average number of episodes of illness was the same for the village and orphanage children. The poorer rates of growth of the village children compared with those of the children in the orphanage was, in all probability, due to their lower energy and protein intakes. However, individual protein intakes showed no correlation with increases in height as, in the majority of the children, the daily requirements of protein were met; the individual energy intakes correlated with gains in weight $(r=0.36)$.

At the end of the ad lib. trial both groups of children at the orphanage showed a fall in haemoglobin of $10-15 \mathrm{~g} / 1$ whereas, in the first trial, the children in the control group maintained their haemoglobin and those in the experimental group had a small rise in haemoglobin. The daily intake of iron from both diets was similar, being $14.2 \mathrm{mg} /$ child per $\mathrm{d}$ in the first study and $13.7 \mathrm{mg} /$ child per $\mathrm{d}$ in the second. However, in the first study just $50 \%$ of the daily iron, whereas in the second, $75 \%$ of the iron was derived from the cereals eaten. The high proportion of cereal iron in the diet used in the second trial was probably responsible for the decrease in haemoglobin.

Both groups of children at the orphanage grew at rates similar to those of North American children of the same age (Nelson, 1964 ). It must therefore be assumed that the rice-based diet provided the protein and energy intakes to maintain such satisfactory rates of growth. The addition of lysine and threonine to the diets of the children in the experimental group conferred no benefit. At the village centre, a good proportion of the children was unable to consume enough food to ensure an adequate intake of energy. In this situation also, the fortification of cereal with lysine and threonine conferred no advantage.

The authors are indebted to Dr K. Akino and the Ajinomoto Co. Inc., Tokyo, Japan, for the generous supply of the rice fortification granules used in this study.

They thank Mrs Molly Mammen and Messrs V. S. Jeevarathnam and P. F. S. Venkatarangam for technical assistance and Mr Sampathkumar Mathews for the statistical analyses of the results.

This study was supported by Agreement No. OI-002-I PL 480 Funds from the National Institutes of Health, United States Public Health Service. 


\section{REFERENCES}

Altschul, A. M. (1967). Science, N.Y. 158, 221.

Begum, A., Radhakrishnan, A. N. \& Pereira, S. M. (1970). Am. F. clin. Nutr. 23, 1175.

Bressani, R., Scrimshaw, N. S., Béhar, M. \& Viteri, F. (1958). F. Nutr. 66, 501 .

FAO (1957). F.A.O. nutr. Stud. no. I5.

Graham, G. G., Morales, E., Cordano, A. \& Placko, R. P. (1971). Am. F. clin. Nutr. 24, 200.

Graham, G. G., Placko, R. P., Acevedo, G., Morales, E. \& Cordano, A. (rq69). Am. Y. clin. Nutr. 22, 1459 .

Holt, L. E. Jr, György, P., Pratt, E. L., Snyderman, S. E. \& Wallace, W. M. (r960). Quoted by Hegsted, D. M. (1964). In Mammalian Protein Metabolism ch. 14, p. 155 [H. N. Munro and L. B. Allison, editors]. New York: Academic Press Inc.

Howe, E. E., Jansen, G. R. \& Anson, M. L. (1967). Am. Y. clin. Nutr. 20, I I34.

Howe, E. E., Jansen, G. R. \& Gilfillian, E. W. (1965). Am. F. clin. Nutr. 16, 3 15.

Indian Council of Medical Research (1966). Spec. Rep. Ser. Indian Coun. med. Res, no. 42.

Indian Council of Medical Research (1968). Spec. Rep. Ser. Indian Coun. med. Res. no. 60.

Jansen, G. R. \& Howe, E. E. (1964). Am. F. clin. Nutr. 15, 262.

King, K. W., Sebrell, W. H. Jr, Severinghaus, E. L. \& Storvick, W. O. (1963). Am. J. clin. Nutr. 12, 36.

Nakagawa, I., Takahashi, T. \& Suzuki, T. (I961). F. Nutr. 74, 4 о г.

National Research Council: Food and Nutrition Board (1968). Publs natn. Res. Coun., Wash. no. 1694.

Nelson, E. W. (1964). Text Book of Pediatrics p. 48. Philadelphia: W. B. Saunders Co.

Pereira, S. M., Begum, A., Jesudian, G. \& Sundararaj, R. (1969). Am. \%. clin. Nutr. 22, 606.

Reinhold, J. G. (1953). Standard Methods of Clinical Chemistry p. 88. New York: Academic Press Inc.

Scrimshaw, N. S., Bressani, R., Béhar, M. \& Viteri, F. (1958). F. Nutr. 66, 485.

Sundararaj, R., Begum, A., Jesudian, G. \& Pereira, S. M. (1969). Indian F. med. Res. 57, 249.

Wait, B., Blair, R. \& Roberts, L. J. (1969). Am. J. clin. Nutr. 22, 1383.

WHO (1965) Tech. Rep. Ser. Wld Hlth Org. no. $30 \mathrm{I}$. 